\title{
Changes of useful components and biological activities of Solanum nigrum Linne fruit according to different harvest time
}

\author{
Seongkyu Choi ${ }^{1}$, Kyeong-Won Yun ${ }^{1}$, Yong-Doo Kim ${ }^{3}$, Seong-Woo Jin ${ }^{2}$, \\ Kyung-Je Kim ${ }^{2}$, Kyeong-Yun Kang ${ }^{4}$, Young-Woo Koh ${ }^{2}$, Seung-bin Im $^{2}$, \\ Sang-Wook Jeong ${ }^{2}$, Kyoung-Sun Seo ${ }^{2 *}$ \\ ${ }^{1}$ Department of Oriental Medicine Resources, Sunchon National University, Suncheon 57922, Korea \\ ${ }^{2}$ Jangheung research institute for mushroom industry, Jangheung 59338, Korea \\ ${ }^{3}$ Department of Food Science and Technology, Sunchon National University, Suncheon 57922, Korea \\ ${ }^{4}$ Department of Pharmacy, Sunchon National University, Suncheon 57922, Korea
}

\section{수확시기에 따른 까마중 열매의 유용성분 및 생리활성 변화}

\author{
최성규 ${ }^{1} \cdot$ 윤경원 $^{1} \cdot$ 김용두 ${ }^{3} \cdot$ 진성 우 $^{2} \cdot$ 김경제 $^{2} \cdot{\text { 강경 }^{3}}^{3} \cdot$ 고영 우 $^{2} \cdot$ 임승빈 $^{2} \cdot$ 정상욱 $^{2} \cdot$ 서경순 $^{2 *}$ \\ ${ }^{1}$ 순천대학교 한약자원개발학과, ${ }^{2}$ (재)장흥군버섯산업연구원, ${ }^{3}$ 순천대학교 식품공학과, \\ ${ }^{4}$ 순천대학교 약학과
}

\begin{abstract}
In this study, we investigated the variation in free sugars, organic acids, antioxidant activity and anti-inflammatory effect of Solanum nigrum Linne fruits according to harvest time. Four kinds of free sugars (fructose, glucose, sucrose, maltose) were detected in $S$. nigrum fruit, and the free sugar contents varied significantly with harvest time. Organic acid content of $S$. nigrum fruit showed the highest in malic acid and acetic acid, and the highest content of total organic acids was found in $S$. nigrum fruit harvested on October $18^{\text {th }}$ and October $25^{\text {th }}$. For the total polyphenol content, S. nigrum fiuit harvested on October $18^{\text {th }}$ was the highest. The strongest DPPH and ABTS radical scavenging activity was showed in $S$. nigrum fruit harvested on October $11^{\text {th }}$ and October $18^{\text {th }}$. The anti-inflammatory activity and antioxidant effects were the highest in the ethanol extract from $S$. nigrum fruit collected on October $18^{\text {th }}$ and October $11^{\text {th }}$. Thus, it seems the best to harvest of $S$. nigrum fruit harvested on October $11^{\text {th }}$ and October $18^{\text {th }}$.
\end{abstract}

Key words : Solanum nigrum fruit, harvest time, useful components, antioxidant, anti-inflammatory

\section{서 론}

까마중(Solanum nigrum L.)은 가지과(Solanaceae)에 속하 는 1년생 초본(草本)으로 아프리카가 원산지로 알려져 있으 며, 전 세계적으로 자생하고 있다(1). 까마중의 열매는 용규 (龍葵), black nightshade로도 불리고 있으며(2), 한방에서 까마중의 전초를 여름과 가을사이에 채취하여 햇볕에 말린

*Corresponding author. E-mail : astragali@daum.net Phone : 82-61-862-8877, Fax : 82-61-862-8847

Received 14 September 2017; Revised 19 October 2017; Accepted 23 October 2017.

Copyright (c) The Korean Society of Food Preservation. All rights reserved.
후 약용으로, 열매는 가을에 수확하여 식용으로 이용한다 $(3,8)$. 이러한 유용성분과 영양성분을 바탕으로 까마중은 세계 각지에서 채소로도 널리 사용되고 있으며, 중국에서 는 고대에 구황작물로도 활용된 기록이 있다(4). 중국에서 도 까마중은 간보호와 항염증제로 사용되어진 바 있다(5). 까마중을 비롯한 과거 약용으로 사용되어 온 천연원료들의 활용은 식물체에 함유된 유용성분을 기반으로 식품 및 기능 식품 개발로 확대되고 있는 추세이다(6). 까마중 전초는 여름과 가을사이가 수확시기로 알려져 있으며(7), 까마중 열매는 용규자라고 하며, 이뇨, 해열 및 피로한 것을 풀어준 다고 기록되어 있다(8).

최근 직장내 스트레스, 환경오염 등으로 인하여 면역활 
성 및 항산화제에 대한 관심이 높아지고 있다(9). 활성산소 종은 superoxide로 대표되며, 식세포에 의한 박테리아 제거 와 같이 항균 및 생리현상에 중요하지만, 활성산소종의 발 생량이 정상치를 넘어서면 생체 내에서 단백질, DNA 및 세포막에 작용하여, 활성을 저하 및 기능의 손실을 유발 할 수 있고(10), 각종 암, 성인병 등 질병을 야기하는 물질로 밝혀진 바 있다 $(11,12)$. Free radical의 유해성에 대한 정보가 많아지면서 활성산소종을 제거해주는 물질을 천연 식품 소재에서 발굴 및 개발하려는 연구가 지속적으로 이루어지 고 있다(13,14).

까마중의 항산화 및 생리활성에 관한 연구들로는 까마중 잎의 acetone, methanol 및 물로 추출하여 항산화 효과를 비교한바 있으며(15), 까마중의 항산화 효과를 나타내는 phenol성 물질이 2,6-methano-3-benzozocin-11-ol, 2-hydroxy5-methyl-benzaldehyde로 보고한 바 있다(16). 까마중에 관 한 연구로는 까마중의 생산(17). 까마중 전초의 생리활성 (18), 수확시기에 따른 까마중 전초의 성분, 생리활성(19)등 이 보고된 바 있다. 이상과 같이 까마중은 유용성과 식품으 로의 개발 가능성이 큰 자원으로 보여진다(20). 따라서 민간 에서 식품 및 건강기능식품 개발과 연관된 이용가치가 있는 까마중을 비롯한 자원들에 대한 체계적인 연구가 요구되어 지고 있다.

까마중 열매는 약용 및 식용 원료로 개발 가능성이 크지 만, 까마중 전초의 최적 수확시기에 열매가 성숙되지 않은 단점이 있다(21). 까마중 열매는 간보호 연구(5), 신경약물 학적 활성(22) 등이 보고된 바 있으나, 식품 소재로 활용을 위한 유리당, 유기산 조성 및 함량에 관한 연구가 수행된 바 없다. 또한 까마중 열매는 전초와 수확시기가 다를 것으 로 생각되나 이에 관한 자료가 전무하여, 까마중 열매를 활용한 식품개발에 어려움으로 지적된다.

이에 본 연구에서는 까마중 열매의 적정 수확시기를 구 명하고자, 결실기부터 성숙기까지 시료를 활보하여 유리 당, 유기산 및 총 polyphenol 함량은 분석 및 측정하였다. 또한 수확시기에 따른 까마중 열매 DPPH radical 소거능, $\mathrm{ABTS}$ radical 소거능, 세포독성평가 및 NO 생성 억제효과 를 실험하여 까마중 열매의 식용소재화의 자료를 제공하고 자 한다.

\section{재료 및 방법}

\section{재료 및 방법}

본 실험에 사용한 까마중은 2015년 10월에 채종한 자생 종의 까마중 종자를 2016년 4월 20일에 순천대학교약초원 에 파종하였으며, 까마중 열매의 결실기인 9월 27일부터 11 월 1 일까지 1 주일 간격으로 6 회 채취하였다(23). 채취한
까마중 열매를 동결건조 한 후 마쇄한 분말을 $100 \mathrm{mesh}$ 체로 걸러서 통과한 분말만을 시료로 사용하였다.

\section{시약 및 용매}

본 실험에 사용한 시약은 Sigma-aldrich(St. Louis, MO, $\mathrm{USA}$ )에서 구입하여 사용하였으며, 아미노산 분석은 AccQTag amino acids assay kit(Waters, Milford, MA, USA)를 사용하였다. 추출 및 분석에 사용한 용매는 시판 특급 및 일급 시약을 사용하였다.

\section{유리당 분석}

유리당 함량은 Wilson 등(24)의 방법에 준하여 분석하였 다. 즉, 시료 $5 \mathrm{~g}$ 에 증류수를 가하여 교반시킨 후 $100 \mathrm{~mL}$ 로 정용하여 원심분리 $(50,000 \mathrm{rpm}, 30 \mathrm{~min})$ 하고 상징액을 취하 여 여과(Whatman No. 2)하였다. 여과한 여액을 Sep-pak $\mathrm{C}_{18}$ 으로 정제시킨 다음, $0.45 \mu \mathrm{m}$ membrane filter(Millipore Co, USA)로 여과 후 HPLC system(1200 series, Agilent, Palo Alto, CA, USA)을 이용하여 수행하였으며, 검출기는 ELSD(1200 series, Agilent, Les Ulis, France), column은 carbohydrate column $(250 \times 4.6 \mathrm{~mm}$, Agilent, Richardson, TX, USA)을 사용하였고, 이동상은 $75 \%$ acetonitrile을 사용하였 다. 유속은 분당 $1.0 \mathrm{~mL}$ 였으며, 시료 주입량은 $10 \mu \mathrm{L}$ 로 하여 실험을 진행하였다.

\section{유기산 분석}

유기산 함량은 유리당의 방법과 동일하게 처리 후 HPLC system(Agilent, USA)을 이용하여 분석하였으며, column은 organic acid column $(250 \times 4.6 \mathrm{~mm}$, Alltech Co., Deerfield, $\mathrm{IL}, \mathrm{USA})$ 을 사용하였고, 이동상은 $25 \mathrm{mM} \mathrm{NaHPO}$ 를 사용 하였다. 유속은 분당 $1.0 \mathrm{~mL}$ 였으며, 검출 파장은 $210 \mathrm{~nm}$, 시료 주입량은 $10 \mu \mathrm{L}$ 로 하여 실험을 진행하였다.

\section{에탄올 추출물 제조}

동결건조된 시료 $1 \mathrm{~g}$ 을 absolute ethanol $50 \mathrm{~mL}$ 에 침지하 고 상온에서 3시간동안 $150 \mathrm{rpm}$ 으로 교반하여 추출하였다. 교반은 Obital shaker(VS-201D, Vision scientific Co., Bucheon, Korea)를 사용하였으며 추출이 끝난 추출물은 Whatman paper No. 2로 filter 하였다. 시료에 에탄올을 증발 시키기 위해 진공회전증발농축기(N-1000S-W, Tokyo rikakikai Co., Tokyo, Japan)를 이용하여 감압 농축하였다. 각 시료는 conical tube 에 넣어 초저온냉장고(MDF-794, Sanyo electric Co., Tokyo, Japan)에서 동결한 후 동결건조기 (PVTFD10R, Ilshin lab Co., Dongducheon, Korea)로 건조하 여 추출물의 분말을 얻었다. 까마중 에탄올추출물 동결건 조 분말들은 아래 Table 1과 같은 수율을 나타내었으며, 실험에 시료로 사용하였다. 
Table 1. Soluble solid content in ethanol extract of Solanum nigrum fruits depending on harvest time

\begin{tabular}{|c|c|c|c|c|c|c|}
\hline & \multicolumn{6}{|c|}{ Harvest time } \\
\hline & Sep. $27^{\text {th }}$ & Oct. $4^{\text {th }}$ & Oct. $11^{\text {th }}$ & Oct. $18^{\text {th }}$ & Oct. $25^{\text {th }}$ & Nov. $1^{\text {st }}$ \\
\hline $\begin{array}{l}\text { Soluble solid } \\
\text { (mg/g) }\end{array}$ & $43.2 \pm 3.1^{1)}$ & $48.3 \pm 2.9$ & $52.2 \pm 3.2$ & $54.7 \pm 2.6$ & $58.4 \pm 4.5$ & $52.2 \pm 4.7$ \\
\hline
\end{tabular}

${ }^{1)}$ Each value represents the mean \pm SD of three determinations.

\section{폴리페놀 함량측정}

페놀함량 측정은 Velioglu 등의 법을 변형한 방법(25)으 로 측정하였다. $1 \mathrm{mg} / \mathrm{mL}$ 에 시료 $5 \mu \mathrm{L}$ 에 10 배 희석한 Folin-Ciocalteau 시약을 $100 \mu \mathrm{L}$ 씩 첨가한 후 상온에서 5 분 간 둔다. 반응 후 각 tube에 $7.5 \% \mathrm{Na}_{2} \mathrm{CO}_{3}$ 를 $500 \mu \mathrm{L}$ 씩 첨가하 고 $30^{\circ} \mathrm{C}$ 에 90 분간 반응한 다음 흡광도 $725 \mathrm{~nm}$ 측정한다. 총 페놀함량은 $100,300,500$ 및 $1,000 \mu \mathrm{g} / \mathrm{mL}$ gallic acid를 이용하여 표준검량선을 작성하여 총 폴리페놀 함량을 시료 $1 \mathrm{mg}$ 중에 $\mu \mathrm{g}$ gallic acid equivalent로 나타내었다.

\section{DPPH radical 소거활성}

전자공여능 측정은 Blois의 방법(26)을 수정하여 측정하 였다. $10,50,100,500 \mu \mathrm{g} / \mathrm{mL}$ 농도의 sample $10 \mu \mathrm{L}$ 에 $2 \times 10^{-4}$ $\mathrm{mM}$ DPPH 용액(dissolved in absolute methanol)을 $90 \mu \mathrm{L}$ 첨가하고 상온에서 30 분간 반응한 후 $517 \mathrm{~nm}$ 에서 흡광도를 측정하였다. 전자공여능은 아래의 식과 같이 백분율 $(\%)$ 을 계산한 후 $\mathrm{IC}_{50}(50 \%$ inhibition concentration)값은 $50 \%$ $\mathrm{DPPH}$ free radical을 제어시키는 시료농도를 계산하였다.

$$
\begin{aligned}
& \text { 전자공여능 }(\%)=(1-\text { 시료 첨가구의 흡광도/무처리 구의 } \\
&\text { 흡광도 }) \times 100
\end{aligned}
$$

\section{ABTS radical 소거활성}

$\mathrm{ABTS}$ radical을 이용한 항산화력 측정은 $\mathrm{ABTS}^{+}$cation decolourisation assay 방법(27)으로 시행하였다. $7 \mathrm{mM}$ 2,2'-azino-bis(3-ethylbenzthiazoline-6-sulfonic acid)와 2.45 $\mathrm{mM}$ potassium persulfate를 혼합하여 $4{ }^{\circ} \mathrm{C}$ 인 암소에서 overnight 동안 반응하여 $\mathrm{ABTS}^{+}$을 형성시킨 후 $734 \mathrm{~nm}$ 에 서 흡광도 값이 $0.70( \pm 0.02)$ 이 되도록 phosphate buffer saline(PBS, $\mathrm{pH}$ 7.4)로 희석하였다. 시료 $10 \mu \mathrm{L}$ 에 희석된 용액 $90 \mu \mathrm{L}$ 를 첨가하여 정확히 5 분 후 $734 \mathrm{~nm}$ 에서 흡광도를 측정하였다. ABTS radical 소거활성은 $\mathrm{DPPH}$ scavenging activity 계산방법과 동일하게 백분율(\%)로 계산한 후 $\mathrm{IC}_{50}$ (inhibitory concentration $50 \%$ )로 표현하였다.

\section{RAW 264.7 세포배양}

RAW 264.7 세포는 $10 \% \mathrm{FBS}$ 와 $1 \%$ antibiotics가 첨가된 $\mathrm{DMEM}$ 배지를 사용하여 $37^{\circ} \mathrm{C}, 5 \% \mathrm{CO}_{2}$ 배양기에서 배양하 였다. 세포는 culture dish에 80-90\% 정도 자랐을 때 계대배
양하였고 cell passage number는 20을 넘기지 않은 세포로만 실험하였다.

\section{세포독성 측정}

시료의 세포독성을 측정하기 위해 Green 등(28)의 방법 에 따라 3-(3,4-dimethyl-thiazolyl-2)-2,5-diphenyl tetrazolium bromide(MTT) assay를 실시하였다. RAW264.7 cell 세포가 $1 \times 10^{5}$ cells $/ \mathrm{mL}$ 의 농도가 되도록 96-well plate에 $100 \mu \mathrm{L}$ 씩 분주하고 $37^{\circ} \mathrm{C}, 5 \% \mathrm{CO}_{2}$ incubator에서 18 시간 동안 배양하 였다. LPS(Lipopolysaccharide, Sigma, MO, St. Luis)와 시료 처리는 $0.5 \% \mathrm{FBS}$ 가 첨가되어 있는 $\mathrm{DMEM}$ 에 희석하여 24 시간 처리하고 $0.5 \mathrm{mg} / \mathrm{mL}$ 의 $\mathrm{MTT}$ 용액을 포함하는 배지로 교체하여 incubator에서 4시간 배양하였다. 배양 종료 후 상등액을 제거하고 각 well에 $150 \mu \mathrm{L} \mathrm{DMSO}$ 를 첨가하여 formazan 결정을 용해시켜 microplate reader(BioTek, Winooski, VT, USA)로 흡광도 $540 \mathrm{~nm}$ 로 측정하였다. 세포 독성은 시료 무처리군의 흡광도에 대비하여 백분율로 나타 내었다.

\section{Nitric oxide(NO) 생성량 측정}

RAW264.7 세포로부터 생성되는 활성 질소종인 nitric oxide(NO)의 양은 Green 등(29)의 방법을 이용하여 세포 배양액 중 존재하는 $\mathrm{NO}^{2-}$ 형태를 Griess Reagent와 반응시켜 측정하였다. RAW264.7 cell을 $1 \times 10^{5}$ cells $/ \mathrm{mL}$ 농도로 96-well plate에 분주한 후 시료를 농도별로 처리하여 24시간 배양 하였다. 세포배양 상등액 $100 \mu \mathrm{L}$ 와 Griess 시약(A reagent, $1 \%$ sulfanilamide; $\mathrm{B}$ reagent, $0.1 \%$ naphthylethylendiamine in $25 \%$ phosphoric acid) 각 $50 \mu \mathrm{L}$ 를 혼합하여 96-well plate에 서 10 분간 반응시킨 후 microplate reader를 이용하여 540 $\mathrm{nm}$ 에서 흡광도를 측정하였다. $\mathrm{NO}^{2-}$ 표준곡선은 $\mathrm{NaNO}_{2}$ 를 농도별로 조제하여 사용하였다.

\section{통계분석}

모든 실험은 3회 반복하였으며, 실험결과를 SPSS 통계프 로그램(Statistical Package for Social Science, version 12.0, SPSS Inc., Chicago, IL, USA) 을 이용하여 평균값과 표준편 차를 산출하였다. 생리활성 실험은 Duncan's multiple test를 통해 그 유의성 $(\mathrm{p}<0.05)$ 을 확인하였다.

\section{결과 및 고찰}

\section{유리당 함량}

까마중 열매의 수확 시기별 유리당 함량을 측정한 결과 fructose, glucose, sucrose, maltose 4가지 유리당이 검출되었 으며, 주요 유리당은 fructose와 glucose로 나타났다(Table 2). 수확시기별 까마중 열매의 총 유리당 함량은 10 월 18 일 
수확한 까마중에서 $7.26 \%$ 로 가장 높게 나타났으며, 10 월 25 일 수확한 까마중, 10 월 11일 수확한 까마중 순으로 유리 당 함량이 높게 나타났다. 모든 시료구에서 fructose 함량이 가장 높게 나타났으며, 다음으로 glucose 함량이 높게 나타 났다.

Table 2. Free sugar contents in water extract of Solanum nigrum fruits depending on harvest time

$(\%)$

\begin{tabular}{cccccc}
\hline $\begin{array}{c}\text { Harvest } \\
\text { time }\end{array}$ & Fructose & Glucose & Sucrose & Maltose & $\begin{array}{c}\text { Total free } \\
\text { sugars }\end{array}$ \\
\hline${\text { Sep. } 27^{\text {th }}}^{\text {th }}$ & $1.78 \pm 0.31^{1)}$ & $1.52 \pm 0.14$ & $0.21 \pm 0.01$ & $0.32 \pm 0.03$ & $3.83 \pm 0.09$ \\
${\text { Oct. } 4^{\text {th }}}^{\text {th }}$ & $2.12 \pm 0.18$ & $1.34 \pm 0.11$ & $0.12 \pm 0.02$ & $0.22 \pm 0.01$ & $3.8 \pm 0.05$ \\
Oct. 11 $^{\text {th }}$ & $2.71 \pm 0.21$ & $1.45 \pm 0.16$ & $0.14 \pm 0.03$ & $0.15 \pm 0.02$ & $4.45 \pm 0.07$ \\
Oct. 18 & $3.12 \pm 0.26$ & $2.02 \pm 0.31$ & ND & $0.12 \pm 0.01$ & $5.26 \pm 0.68$ \\
Oct. $25^{\text {th }}$ & $3.21 \pm 0.27$ & $1.57 \pm 0.23$ & $\mathrm{ND}$ & $\mathrm{ND}$ & $4.78 \pm 0.18$ \\
Nov. $1^{\text {th }}$ & $2.74 \pm 0.26$ & $2.10 \pm 0.21$ & $\mathrm{ND}$ & $\mathrm{ND}$ & $4.84 \pm 0.17$ \\
\hline
\end{tabular}

${ }^{1)}$ Each value represents the mean $\pm \mathrm{SD}$ of three determinations.

${ }^{2)} \mathrm{ND}$, not detected.

Sucrose는 9월 27일 수확한 까마중 열매, 10 월 4일 까마중 열매 및 10 월 11 일에 수확한 까마중 열매에서만 검출되었 으며, maltose는 9월 27일부터 10월 18일까지 수확한 까마 중에서만 검출되었다. 식물에 함유되어 있는 유리당은 항 산화 효과, 항염증 효과 등과 관련되는 것으로 알려져 있는 데(30), 기존 연구에서 인삼열매의 수확시기에 따른 유리당 함량은 개화 후 수확기가 늦어짐에 따라 총 유리당 함량이 증가하였으며, fructose 함량은 수확시기가 늦어짐에 따라 감소한다고 보고하여 본 연구와 차이를 보였다(31). 본 연구 에서 최종 수확시기인 11 월 1 일 수확한 까마중 열매에서 sucrose 및 maltose의 함량감소가 나타났는데, 까마중과 같 은 가지과 식물인 가지의 수확시기에 따른 유리당 함량은 수확시기가 늦어짐에 따라 glucose 및 sucrose 함량이 낮아 졌다는 보고(32)와 유사성을 나타내었다.

\section{유기산 함량}

까마중 열매의 수확 시기별 유기산 분석결과 oxalic acid, malic acid, citric acid 및 acetic acid 총 4종이 검출되었으며, malic acid와 acetic acid의 함량이 모든 시료구에서 높게 나타났다(Table 3). 수확기별 총 유기산 함량은 10 월 18 일과 10 월 19 일에 수확한 까마중 열매에서 가장 높았으며, 10 월 25 일 수확한 까마중 열매, 11 월 1일 수확한 까마중 열매와 10 월 11월에 수확한 까마중 열매 순으로 높은 함량을 나타 내었다. 검출된 유기산 중 malic acid 함량은 10 월 18 일에 수확한 까마중 열매에서 가장 높게 나타났으며, 10 월 11일 수확한 까마중 열매, 10 월 4일 수확한 까마중 열매 순으로 높은 함량을 보였다.
Table 3. Organic acid contents in water extract of Solanum nigrum fruits depending on harvest time

$(\%)$

\begin{tabular}{cccccc}
\hline $\begin{array}{c}\text { Harvest } \\
\text { time }\end{array}$ & Oxalic acid & Malic acid & Citric acid & Acetic acid & $\begin{array}{c}\text { Total organic } \\
\text { acids }\end{array}$ \\
\hline Sep. $27^{\text {th }}$ & $0.14 \pm 0.01^{1)}$ & $0.56 \pm 0.04$ & $0.13 \pm 0.02$ & $0.54 \pm 0.04$ & $1.37 \pm 0.02$ \\
Oct. $4^{\text {th }}$ & $0.06 \pm 0.01$ & $0.69 \pm 0.03$ & $0.17 \pm 0.01$ & $0.68 \pm 0.03$ & $1.6 \pm 0.01$ \\
Oct. $11^{\text {th }}$ & $0.05 \pm 0.02$ & $0.85 \pm 0.05$ & $0.19 \pm 0.01$ & $0.61 \pm 0.05$ & $1.7 \pm 0.02$ \\
Oct. $18^{\text {th }}$ & $0.08 \pm 0.01$ & $0.93 \pm 0.02$ & $0.29 \pm 0.03$ & $0.66 \pm 0.07$ & $1.96 \pm 0.02$ \\
${\text { Oct. } 25^{\text {th }}}$ & $0.04 \pm 0.01$ & $0.62 \pm 0.04$ & $0.47 \pm 0.02$ & $0.81 \pm 0.02$ & $1.94 \pm 0.01$ \\
Nov. $1^{\text {th }}$ & $0.09 \pm 0.02$ & $0.63 \pm 0.03$ & $0.29 \pm 0.04$ & $0.69 \pm 0.05$ & $1.7 \pm 0.02$ \\
\hline
\end{tabular}

${ }^{1)}$ Each value represents the mean $\pm \mathrm{SD}$ of three determinations.

기존 보고에서 까마중의 주요 유기산은 acetic acid, tartaric acid, malic acid 및 citric acid 라고 보고 된 바 있으나 (33), 본 연구에서는 tartaric acid는 검출되지 않았고, oxalic acid가 검출되는 차이점을 보였다.

\section{총 polyphenol 함량측정}

수확시기에 따른 까마중 열매 ethanol 추출물의 총 polyphenol 함량을 측정한 결과는 Table 4 와 같다. 10 월 18 일 에 수확한 까마중 열매 ethanol 추출물의 총 polyphenol 함량 은 $311.26 \mu \mathrm{g} / \mathrm{mg}$ 으로 가장 높게 나타났고, 10월 11일에 수확 한 까마중 열매 ethanol 추출물 $(289.33 \mu \mathrm{g} / \mathrm{mg}$ )과 10 월 25 일 에 채취한 까마중 열매 ethanol 추출물 $(278.12 \mu \mathrm{g} / \mathrm{mg})$ 에서도 높은 수준의 총 polyphenol 함량이 나타났다.

폴리페놀계 물질은 식물계에 널리 분포되어 있는 2 차 대사산물 중 하나로 항산화 활성, 항암 및 항균 작용을 하는 생리활성물질로 알려져 있다(34). 까마중의 주요 폴리페놀 성분은 gallic acid, protocatechuic acid, epicatechin, rutin, caffeic acid을 비롯하여 다수의 성분들이 포함된 것으로 보고된 바 있으며(35), 항균, 항염증 및 항산화 효과를 나타 낸다고 알려져 있다 $(36,37)$ 본 연구 결과 10 월 11 일에서 10 월 25일 수확한 까마중 열매 ethanol 추출물의 폴리페놀

Table 4. Total polyphenol content in ethanol extract of Solanum nigrum fruits based on harvest time

\begin{tabular}{cc}
\hline Harvest time & Content $(\mu \mathrm{g} \mathrm{GAE} / \mathrm{mg}$ extract $)$ \\
\hline Sep. $27^{\text {th }}$ & $231.14 \pm 9.82^{1) \mathrm{d} 2)}$ \\
Oct. $4^{\text {th }}$ & $254.74 \pm 5.71^{\mathrm{c}}$ \\
Oct. $11^{\text {th }}$ & $289.33 \pm 7.28^{\mathrm{b}}$ \\
Oct. $18^{\text {th }}$ & $311.26 \pm 3.21^{\mathrm{a}}$ \\
Oct. $25^{\text {th }}$ & $278.12 \pm 6.31^{\mathrm{b}}$ \\
Nov. $1^{\text {th }}$ & $264.32 \pm 7.15^{\mathrm{c}}$ \\
\hline
\end{tabular}

${ }^{1)}$ Each value represents the mean \pm SD of three determinations GAE ( $\mu$ g gallic acid equivalent/mg ethanol extract equivalents).

${ }^{2)}$ Mean with different superscripts (a-d) are significantly different at $p<0.05$ by Duncan's multiple range test. 
함량은 까마중 열매 추출물의 총 폴리페놀 함량이 $235 \mathrm{mg} / \mathrm{g}$ 이라는 기존의 보고(38) 보다 높게 나타났으며, 포도의 수확 시기에 따른 catechin 함량은 품종별로 차이가 있었지만 대부분의 품종에서 수확시기가 늦어짐에 따라 증가한다는 보고(39)와 유사한 결과를 보였다.

\section{DPPH radical 소거능}

수확시기에 따른 까마중 열매 ethanol 추출물들의 DPPH radical의 소거능을 확인한 결과는 Table 5 와 같다. 수확시기 에 따른 까마중열매 ethanol 추출물들의 DPPH radical 소거 활성은 10 월 18 일에 수확한 까마중 열매 ethanol 추출물과 10 월 11 일에 수확한 까마중 열매 ethanol 추출물에서 낮은 $\mathrm{IC}_{50}$ 값을 나타내어, 높은 항산화 효과를 확인하였다. 다음 으로 10 월 25 일에 수확한 까마중 열매 ethanol 추출물, 10 월 4 일 수확한 까마중 열매 ethanol 추출물, 9월 27일에 수확한 까마중 ethanol 추출물, 11 월 1 일에 수확한 까마중 열매 ethanol 추출물 순으로 낮은 $\mathrm{IC}_{50}$ 값을 나타내었다. 본 연구 결과 까마중 열매 ethanol 추출물의 DPPH radical 소거능은 까마중 지상부 ethanol 추출물 $\left(\mathrm{IC}_{50}, 159.62-184.89 \mathrm{\mu g} / \mathrm{mL}\right)$ 와 지하부 ethanol 추출물 $\left(\mathrm{IC}_{50}, 137.90-179.87 \mathrm{\mu g} / \mathrm{mL}\right)$ 의 $\mathrm{IC}_{50}$ 값(19)보다 낮게 나타나, 까마중 열매 ethanol 추출물의 항산 화 효과가 다른 부위 추출물보다 높음을 확인하였다.

Table 5. $\mathrm{IC}_{50}$ of DPPH radical-scavenging activity and ABTS radical- scavenging activity of ethanol extract of Solanum nigrum fruits depending on harvest time

\begin{tabular}{ccc}
\hline \multirow{2}{*}{ Samples } & IC $_{\mathbf{5 0}}$ of $\mathbf{D P P H}$ radical $\mathbf{I C}_{\mathbf{5 0}}$ of ABTS radical \\
\cline { 2 - 3 } & \multicolumn{2}{c}{ scavenging activity $(\mu \mathrm{g} / \mathrm{mL})$} \\
\hline Ascorbic acid & $6.15 \pm 0.34^{2)}$ & $2.84 \pm 0.17$ \\
BHT & $12.78 \pm 1.26$ & $3.56 \pm 0.10$ \\
Sep. $27^{\text {th }}$ & $134.89 \pm 2.49^{\mathrm{c})}$ & $105.48 \pm 2.16^{\mathrm{ab}}$ \\
Oct. $4^{\text {th }}$ & $137.10 \pm 4.12^{\mathrm{c}}$ & $101.67 \pm 3.43^{\mathrm{ab}}$ \\
Oct. $11^{\text {th }}$ & $113.62 \pm 3.14^{\mathrm{ab}}$ & $93.62 \pm 4.50^{\mathrm{a}}$ \\
Oct. $18^{\text {th }}$ & $106.43 \pm 4.57^{\mathrm{a}}$ & $97.48 \pm 3.07^{\mathrm{a}}$ \\
Oct. $25^{\text {th }}$ & $129.87 \pm 5.82^{\mathrm{c}}$ & $112.14 \pm 2.57^{\mathrm{c}}$ \\
Nov. $1^{\text {th }}$ & $154.68 \pm 4.33^{\mathrm{d}}$ & $124.86 \pm 2.33^{\mathrm{d}}$ \\
\hline
\end{tabular}

${ }^{1)} \mathrm{BHT}$, dibutyl hydroxy toluene.

${ }^{2)}$ Each value represents the mean \pm SD of three determinations.

${ }^{3)}$ Mean with different superscripts (a-c) are significantly different at $\mathrm{p}<0.05$ by Duncan's multiple range test.

\section{ABTS radical 소거능}

까마중 열매 ethanol 추출물들의 ABTS 라디칼의 소거능 을 확인한 결과는 Table 5 와 같다. 수확시기에 따른 까마중 열매 ethanol 추출물들의 ABTS radical 소거능은 10 월 11 일 에 채취한 까마중 열매 ethanol 추출물과 10 월 18 일에 수확 한 까마중 열매 ethanol 추출물들에서 낮은 $\mathrm{IC}_{50}$ 값을 나타내 어, ABTS radical 소거활성이 가장 강하였으며, 10 월 4 일
수확한 까마중 열매 ethanol 추출물, 9월 27일에 수확한 까 마중 열매 ethanol 추출물, 10 월 25일에 수확한 까마중 ethanol 순으로 높은 ABTS radical 소거작용이 나타났다. 대조구인 ascorbic acid는 $2.84 \mu \mathrm{g} / \mathrm{mL}$ 의 $\mathrm{IC}_{50}$ 값을 나타냈으 며, BHT는 $3.56 \mu \mathrm{g} / \mathrm{mL}$ 의 $\mathrm{IC}_{50}$ 값을 보였다. 또한 식물유래 항산화 물질은 인체내에서 생성된 자유라디칼의 활성을 억제하여 항산화 효과를 나타낸다는 기존 보고(40)와 같이 까마중 열매 ethanol 추출물은 천연 항산화제로서의 활용이 기대된다.

\section{세포독성 및 RAW 264.7 세포의 염증억제 효능}

수확시기를 달리하여 수확한 까마중 열매 ethanol 추출물 들의 세포독성을 평가하고자 3-(3,4-dimethyl- thiazolyl-2)2,5-diphenyl tetrazolium bromide assay(MTT assay)를 수행 하였으며(41), RAW 264.7은 외인성 산화 스트레스로부터 세포보호효과 검정 및 염증을 유발하는 lipopolysaccharide (LPS)나 sodium nitroprusside(SNP)의 방어 기작 연구에 주 로 사용되는 세포주다(42). 까마중 열매 ethanol 추출물들의 세포독성 평가에서 까마중 열매 ethanol 추출물들을 10,50 , $100 \mu \mathrm{g} / \mathrm{mL}$ 의 농도로 처리한 시험구들에서 $100 \mu \mathrm{g} / \mathrm{mL}$ 의 농도에서도 RAW 264.7 cell의 세포생존율이 90\%이상을 나타내어, 세포독성은 없는 것으로 확인하였다(Fig. 1). 세 포독성은 나타나지 않았으나 세포 생존율은 까마중 열매의 수확시기가 늦어질수록 높아짐을 확인하였는데, 이는 까마 중 열매 결실기에 작은 열매에서는 독성을 유발 할 수 있는 solasodine의 함량이 높게 나타났으나 성숙함에 따라 solasodine의 함량은 낮아진다는 보고와 관련성이 높은 것 으로 생각된다(43).

RAW 264.7 cell에 $1 \mu \mathrm{g} / \mathrm{mL}$ LPS를 처리하여 NO 생성량이 $13.23 \mu \mathrm{M}$ 로 증가됨을 확인하였으며, 10 월 18 일에 수확한 까마중 열매 ethanol 추출물을 $10,50,100,500 \mu \mathrm{g} / \mathrm{mL}$ 의

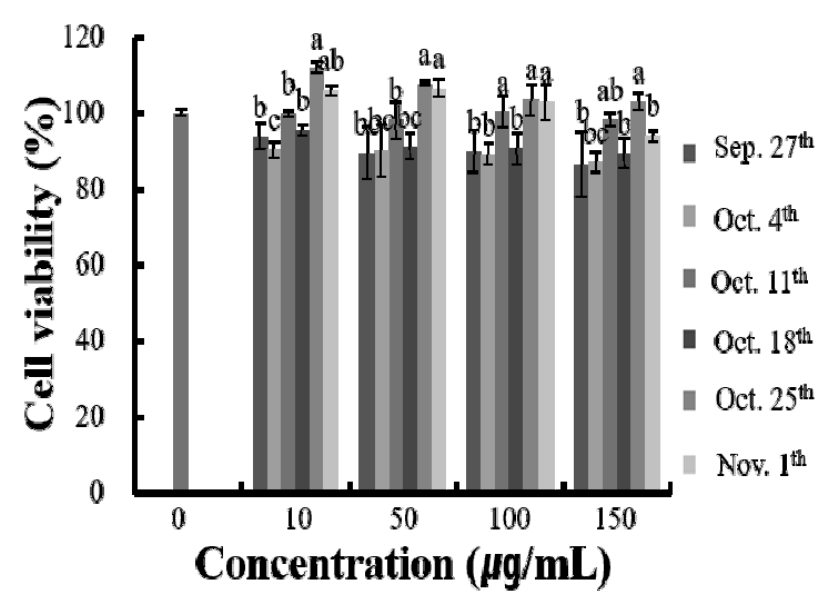

Fig. 1. The effect of Solanum nigrum fruits ethanol extracts on the cell viability of RAW 264.7 cells.

Mean with different superscripts (a-c) are significantly different at $p<0.05$ in same concentrations by Duncan's multiple range test. 
농도로 LPS와 동시 처리한 배지에서 NO 생성량을 측정한 결과 $10.3,10.7,10.1,9.6 \mu \mathrm{M}$ 로 가장 낮게 나타났다(Fig. 2). 10 월 11 일에 수확한 까마중 열매 ethanol 추출물은 11.2 , $11.0,10.1,9.4 \mu \mathrm{M}$ 의 NO 생성량을 보였으며, 10 월 4일에 채취한 까마중 열매 ethanol 추출물 처리군의 NO 생성량은 $11.6,11.5,11.2,10.4 \mu \mathrm{M}$ 로 약간 감소하였다. 그리고 9월 27일에 채취한 까마중 열매 ethanol 추출물의 처리군에서 $\mathrm{NO}$ 생성량은 $11.9,11.5,11.2,10.6 \mu \mathrm{M}$ 로 나타났으나, 10 월 25 일 채취한 까마중 열매 ethanol 추출물과 11 월 1 일 채취한 까마중 열매 ethanol 추출물은 오히려 NO 생성량이 높아져 항염증 효과가 나타나지 않았다. 기존 연구에서 까마중 전 초는 항염증 작용과 진통작용이 있는 것으로 알려진 바 있으며(44), 본 연구 결과 항산화 효과와 항염증 작용은 연관관계가 있다는 기존 보고(19)와 유사성을 나타내었다. 본 실험의 폴리페놀 함량, 항산화 효과 및 항염증 활성은 연관성을 보였다. 항염증 실험 결과를 종합해 볼 때, 10 월 18 일에 채취한 까마중 열매 ethanol 추출물의 항염증 효과 가장 높게 측정되었으며, 10 월 18 일 이전에 수확한 까마중 열매 ethanol 추출물들은 농도 의존적으로 $\mathrm{NO}$ 의 함량 감소 효과를 나타내었다.

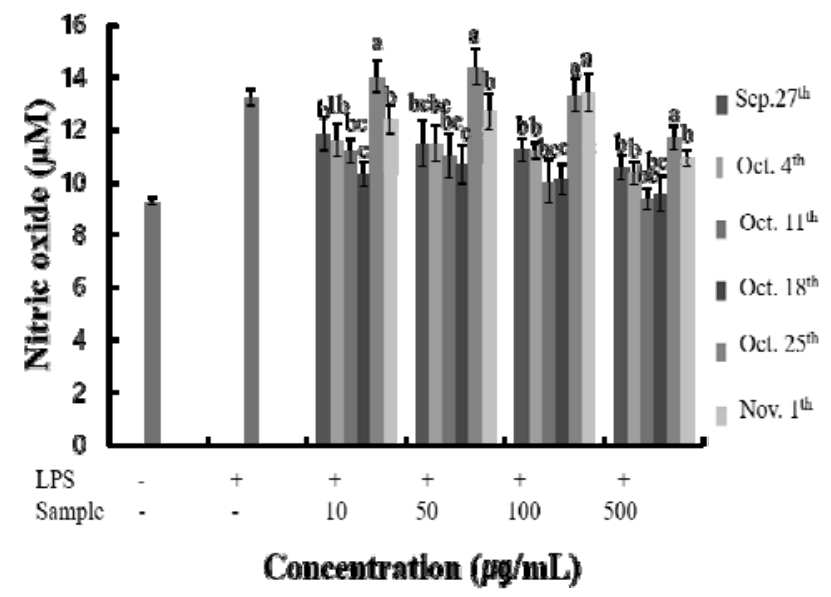

Fig. 2. Anti-inflammation effect of Solanum nigrum fruits ethanol extract lipopolysaccharide(LPS)-induced on RAW264.7 cells.

Mean with different superscripts (a-c) are significantly different at $p<0.05$ in same concentrations by Duncan's multiple range test.

\section{요 약}

본 연구는 까마중 열매의 수확시기에 따른 성분변화, 항 산화효과 및 항염증 효과를 분석하여 최적 수확시기를 구명 하였다. 까마중 열매의 유리당은 4 가지가 검출되었으며, 유리당 중 fructose는 대체적으로 수확시기가 늦어짐에 따 라 증가하였다. 까마중 열매의 주요 유기산은 malic acid와 acetic acid로 나타났으며, 총 유기산 함량은 10 월 18 일과 10 월 25일에 수확한 까마중 열매들에서 높게 나타났다. 총
폴리페놀 함량은 10 월 18 일에 수확한 까마중 열매, 10 월 11 일에 수확한 까마중 열매 및 10 월 25일에 수확한 까마중 열매 순으로 높게 나타났다.

수확시기별 까마중 ethanol 추출물들의 항산화효과와 항 염증효과 검정을 위하여 DPPH radical scavenging assay와 ABTS radical scavenging assay를 수행하였으며, 항염증 효 과 측정을 위하여 lipopolysaccharide(LPS)로 염증을 유발시 킨 RAW 264.7 cells을 NO 저해실험에 사용하였다. 항산화 효과와 항염증 효과는 10 월 18 일에 수확한 까마중 열매 ethanol 추출물에서 가장 높은 활성을 나타내었다. 10 월 18 일에 수확한 까마중 열매는 총 폴리페놀 함량, 항산화 효과 및 항염증 효과가 우수하였다. 까마중 열매의 수확시기에 따른 성분분석 및 생리활성 실험 결과, 까마중 열매의 최적 수확시기는 성숙 중기인 10 월 18 일과 10 월 11 일로 밝혀졌 다.

\section{감사의 글}

이 논문은 2017년 국립 순천대학교 학술연구로 수행되었음.

\section{References}

1. Cooper MR, Johnson AW (1984) Poisonous plants in Britain and their effects on animals and man. Fisheries Food, 161, 219-220

2. Ding X, Zhu F, Yang Y, Li M (2013) Purification, antitumor activity in vitro of steroidal glycoalkaloids from black nightshade (Solanum nigrum L.). Food Chem, 141, 1181-1186 INN

3. Yun KY, Kim MY (2010) Flora of Korean Medicinal Plant. Shinkwang Publishing Co, Seoul, Korea, p 332-333

4. Bradley V, Collins DJ, Crabbe PG, Eastwood FW, Irvine MC, Swan JM, Symon DE (1978) A survey of Australian Solanum plants for potentially useful sources of solasodine. Aus J Bot, 26, 723-754

5. Raju K, Anbuganapathi G, Gokulakrishnan V, Rajkapoor B, Jayakar B, Manian S (2003) Effect of dried fruits of Solanum nigrum LINN. against CCl4-induced hepatic damage in rats. Biol Pharm Bull, 26, 1618-1619

6. Edmonds JM, ChweyaJA (1997) Black nightshades, Solanum nigrum $\mathrm{L}$. and related species. International Plant Genetic Resources Institute, Rome, Italy, p 28

7. Yun KY, Kim MY (2010) Flora of Korean medicinal plant. Shinkwang Publishing Co, Seoul, Korea, p 332-333

8. Huh J (2007) Dong-eu-bo-gam. Bubin Publishing Co, 
Seoul, Korea, p 1945

9. Joo SY (2013) Antioxidant activities of medicinal plant extracts. J Korean Soc Food Sci Nutr, 42, 512-519

10. Ahn BS, Kim JW, Kim HT, Lee SD, Lee KW (2010) Antioxidant effects of Hovenia Dulcis in the streptozotocininduced diabetic rats. J Vet Clin, 27, 366-373

11. Tampo Y, Tsukamoto M, Yonaha M (1999) Superoxide production from paraquat evoked by exogenous NADPH in pulmonary endothelial cells. Free Radic Biol Med, 27, 588-595

12. Oh SI, Lee MS (2005) Antioxidative and antimutagenic effects of Ganoderma lucidum Krast extracts. Korean J Food Nutr, 18, 54-62

13. Kim MJ, Chu WM, Park EJ (2012) Antioxdant and antigenotoxic effects of Shiitake mushrooms affected by different drying methods. J Korean Soc Food Sci Nutr, 41, 1041-1048

14. Cheung LM, Cheung PCK (2005) Mushroom extracts with antioxidant activity against lipid peroxidation. Food Chem, 89, 403-409

15. Jimoh FO, Adedapo AA, Afolayan AJ (2010) Comparison of the nutritional value and biological activities of the acetone, methanol and water extracts of the leaves of Solanum nigrum and Leonotis leonorus. Food Chem Toxicol, 48, 964-971

16. Lim JK, Chung GY, Jeong HJ (2001) Evaluation of the antioxidant potential and identification of active principles of Solanum nigrum L. on antioxidant defense systems. Korean J Life Sci, 11, 509-516

17. Choi SK, Seo KS (2012) Studies on growth charcateristics and yield of Solanum nigrum L. Korean J Plant Res, 25, 596-602

18. Seong JS, Kim KM, Suh JY, Ha JH, Park SN (2015) Antioxidative activities of whole plant extracts of Solanum nigrum L.. J Korean Oil Chemists' Soc, 32, 781-788

19. Choi SK, Seo KS, Kim YD, Yun KW, Choi BS, Jin SW, Kang KY, Cho IK, Kim KJ (2016) The chemical constituents, antioxidant activity and anti-inflammatory activities of Solanum nigrum Linne by different harvest time. Korean J Food Preserv, 23, 866-875

20. Atanu FO, Ebiloma UG, Ajayi EI (2011) A review of the pharmacological aspects of Solanum nigrum Linn.. Biotechnol Mol Biol Rev, 6, 1-7

21. Oh JS (2012) Seed germination and plant growth characteristics of Solanum nigrum Linne influenced by seed soaking and chilling treatments. MS Thesis, Sunchon
National University, Korea, p 17-20

22. Perez GRM, Perez LJA, Garcia DLM, Sossa MH (1998) Neuropharmacological activity of Solanum nigrum fruit. J Ethnopharmacol, 62, 43-48

23. Song MJ (2012) Growth characteristics of Solanum nigrum Linne by the planting density and planting date. MS Thesis, Sunchon National University, Korea, p 17-20

24. Wilson AM, Work TM, Bushway AA, Bushway RJ (1981) HPLC determination of fructose, glucose and sucrose in potatoes. J Food Sci, 46, 300-301

25. Velioglu YS, Mazza G, Gao L, Oomah BD (1998) Antioxidant activity and total phenolics in selected fruits, vegetables, and grain products. J Agric Food Chem, 46, 4113-4117

26. Blois MS (1958) Antioxidant determinations by the use of a stable free radical. Nature, 181, 1199-1200

27. Re R, Pellegrini N, Proteggente A, Pannala A, Yang M, Rice-Evans C (1999) Antioxidant activity applying an improved ABTS radical cation decolorization assay. Free Radical Biol Med, 26, 1231-1237

28. Green LM, Reade JL, Ware CF (1984) Rapid colorimetric assay for cell viability: Application to the quantitation of cytotoxic and growth inhibitory lymphokines. J Immunol Methods, 70, 257-268

29. Green LC, Wagner DA, Glogowski J, Skipper PL, Wishnok JS, Tannenbaum SR (1982) Analysis of nitrate, nitrite, and $\left[{ }^{15} \mathrm{~N}\right]$ nitrate in biological fluids. Anal Biochem, 126, 131-138

30. Jing H, Kitts DD (2004) Antioxidant activity of sugarlysine Maillard reaction products in cell free and cell culture systems. Arch Biochem Biophys, 429, 154-163

31. Lee JC (1988) Changes in contents of ginsenosides, free sugars and fatty acids in developing ginseng seed. Korean J Crop Sci, 33, 134-137

32. Nam HS, Kim NW, Choi YO, Youn KS, Shin SR (2002) Changes on the physical properties and components of export eggplants according to cultivar and harvesting season. Korean J Food Preserv, 9, 287-291

33. Sun Rl, Zhou Q-x, Wang X (2006). Relationships between cadmium accumulation and organic acids in leaves of Solanum nigrum L. as a cadmium -hyperaccumulator. Huan jing ke xue, 27, 765-769

34. Ferreres F, Gomes D, Valentano P, Goncalves R, Pio R, Chagas EA, Seabra RM, Andrade PB (2009) Improved loquat (Eriobotrya japonica Lindl.) cultivars: Variation of phenolics and antioxidantive potential. Food Chem, 114, 1109-1027 
35. Ravi V, Saleem TSM, Maiti PP, Gauthaman K, Ramamurthy J (2009) Phytochemical and pharmacological evaluation of Solanum nigrum Linn.. Afr J Pharm Pharmacol, 3, 454-457

36. Rani P, Khullar N (2004) Antimicrobial evaluation of some medicinal plants for their anti-enteric potential against multi-drug resistant Salmonella typhimurium. Phytother Res, 18, 670-673

37. Lee SJ, Lim KT (2003) Antioxidative effects of glycoprotein isolated from Solanum nigrum Linne on oxygen radicals and its cytotoxic effects on the MCF-7 cell. J Food Sci, 68, 466-470

38. Son YO, Kim J, Lim JC, Chung Y, Chung GH, Lee JC (2003) Ripe fruits of Solanum nigrum L. inhibits cell growth and induces apoptosis in MCF-7 cells. Food Chem Toxicol, 41, 1421-1428

39. Lee SH, Kim SK, Hong EY, Chun SH, Son IC, Kim DI (2014) Effect of harvest time on the several phenolic compounds and fruit quality of grape cultivars. Korean J Plant Res, 27, 119-124
40. Cha JY, Cho YS (1999) Effect of potato polyphenolics on lipid peroxidation in rats. J Korean Soc Food Sci Nutr, 28, 1131-1136.

41. Jo JJ, Shin MG, Kim ES, Lee YS, Shin YJ, Jeon SY (2014) Cytoprotective effects of Platycodon grandiflorus (Jacq.) A.DC on C6 glioma cell apoptosis by oxidative stress. Korean J Oriental Physiology Pathology, 28, 396-402

42. Hu K, Kobayshi H, Dong A, Jing Y, Iwasaki S, Yao X (1999) Antineoplastic agents. III: Steroidal glycosides from Solanum nigrum. Planta medica, 65, 35-38

43. Zakaria ZA, Gopalan HK, Zainal H, Pojan NHM, Morsid NA, Aris A, Sulaman MR (2006) Antinociceptive, anti-inflammatory and antipyretic effects of Solanum nigrum chloroform extract in animal models. Pharm Soc Japan, 126, 1171-1178

44. Jeong KS, Lee NG (2009) Functional properties and antioxidant effect of Solanum nigrum-ethanol extract. J Env Sci Intern, 18, 1207-1214 